\title{
OVERCOMing RESISTANCE TO CHANGE ViA MANAGERIAL ROLE-Play SimUlation
}

\author{
ZGODAVOVA, K.
}

Abstract: The paper presents a new method for the acquirement of new knowledge and skills by means of Role-Play Simulation. The substance of the method rests in team experimentation with a model of Quality Management System prepared in advance. Experimentation may be applied to any of organizational structure, strategy, quality policy and quality objectives, selection of the quality management system model, managerial roles, and all quality management processes. One of the main assets of such experiments is "the overcoming of resistance to change". The final solution to the Quality Management Role-Play Simulation can be achieved in a consensus among role-play participants on the basis of value analysis of submitted partial solutions. The paper is intended for all professionals who are concerned with educational theory, human behaviour theory and/or new methodologies in the field of Quality Management System. The paper is written as a part of work on the research project KEGA 3/6411/08 Transformation of an existing study programme Production Quality Management into a university bilingual study program.

Key words: role-play, simulation, quality, resistance, change
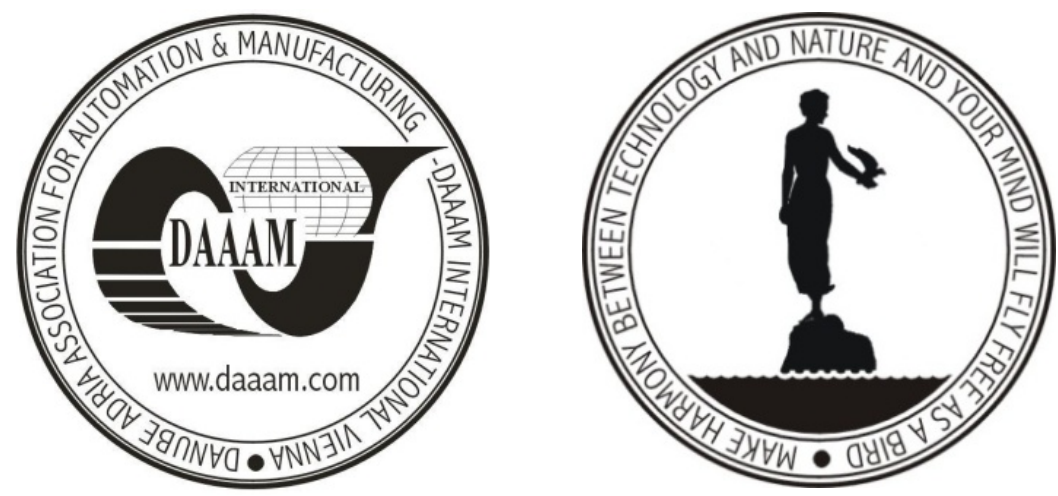

Authors' data: Univ. Prof. Dipl.-Ing. Zgodavova, K[ristina], Alexander Dubcek University of Trencin, Studentska 2, 91150 Trencin, Slovakia, zgodavova@tnuni.sk

This Publication has to be referred as: Zgodavova, K[ristina] (2009). Overcoming Resistance to Change Via Managerial Role-Play Simulation, Chapter 24 in DAAAM International Scientific Book 2009, pp. 223-232, B. Katalinic (Ed.), Published by DAAAM International, ISBN 978-3-901509-69-8, ISSN 1726-9687, Vienna, Austria DOI: $10.2507 /$ daaam.scibook.2009.24 